\title{
Annelid coenoses of wetlands representing different decomposer communities
}

\author{
Anneke Beylich and Ulfert Graefe
}

\section{Abstract}

Annelid coenoses in wet soils reveal specific characteristics in relation to the prevailing complex of abiotic and biotic factors effective in these soils. Especially, the presence or lack of oxygen in the topsoil is of great influence for species composition and vertical distribution of annelids in wet soils. Some annelids, for example most of the smaller enchytraeids, avoid the anaerobic conditions by inhabiting only the uppermost layer of the soil. Others have developed a tolerance against low oxygen contents, either by physiological or by behavioural adaptation. In particular, some earthworm species are capable of penetrating anaerobic soil zones.

Besides soil moisture conditions, base saturation and acidity are decisive for the species composition in soil. While some annelid species are comparatively indifferent to soil moisture and acidity, others tolerate only a rather narrow range of these parameters. For the latter, indicator values for soil reaction and soil moisture have been defined previously. Based on this knowledge the species composition found in a soil gives a differentiated picture of the prevailing living conditions. Furthermore, the occurrence of characteristic species allows us to determine the decomposer community for a given site. The information derived from determining the decomposer community integrates the influence of abiotic and biotic conditions fluctuating over time. The counteractions between water balance and decomposer community are discussed on the basis of data from various wetland habitats in Germany.

\section{Introduction}

Annelid coenoses, comprising earthworms and microannelids (enchytraeids, tubificids and polychaetes), show specific differences depending on the soil properties. In well aerated soils with aeromorphic humus forms we find a sequence of typical annelid coenoses following a gradient from low to high base saturation, as reported previously by Graefe (1993a). Referring to these results, special features of the annelid coenoses of wet soils are discussed in the following. The occurrence of site-specific annelid coenoses can be used in biological characterisation and evaluation of soils (Graefe 1997). A species list should be interpreted considering the whole knowledge of the species ecological behaviour which may be expressed in 
form of indicator values. A further step of data aggregation is the determination of decomposer community types. To illustrate this, we will present the results of investigations at several wet sites (fens, bogs and floodplains).

\section{Soil moisture as main abiotic factor influencing annelid occurrence}

Soil moisture limits the occurrence of terrestrial annelids horizontally and vertically. On the one hand, drought has an adverse effect on annelids, as they do not possess protective structures against evaporation and dry out very quickly under dry conditions. On the other hand, water excess may also be harmful. Earthworms and enchytraeids can survive up to several months when submerged in freshwater as long as the oxygen content is sufficient (Roots 1956; Dunger 1983). Some earthworm species are able to survive by means of anaerobic metabolism for about two days in case of anoxia (Zebe and Heiden 1983; Walenciak 1998). In general, several short periods of flooding or water-logging are apparently more easily tolerated than a single wet period extending over several months. The oxygen concentration in soil, and consequently the earthworms' survival, depends, among other factors, on temperature and microbial activity.

A concept of indicator values was developed for annelids based on the knowledge available so far concerning species preferences and requirements (Graefe 1993a). This concept was inspired by the Ellenberg indicator value system for plants (Ellenberg et al. 1992). In its present state, it consists of indicator values for soil moisture, soil acidity and salinity. Next to soil moisture, soil acidity has long been recognised as decisive for species distribution of annelids (Healy 1980; Bouché 1972). It has been argued that annelids, due to their soft and moist body surface, might be more susceptible to these factors than arthropods for example. However, not all species are equally sensitive: some are confined to soils with either low, medium or high acidity (indicator species) while others tolerate a broad range of conditions (indifferent behaviour). For the latter, no indicator values can be defined. The indicator values for soil acidity and soil moisture provide a differentiated picture of the living conditions for the annelid coenosis in the investigated soil. It is important to note that a certain abiotic factor - such as soil moisture - can be of varying relevance in different ecosystems. In other words, the same moisture regime might be related to different living conditions in different soils, because it affects the soil fauna together with a network of other abiotic and biotic factors. Indicator species provide a means of integration over and above these factors.

An example for a species list, enlarged by the indicator values $F$ and $R$, is given in Table 1. For comparing sites, we also calculated the weighted average indicator values. Additional information on the examined sites is listed in Table 2. 
Table 1. Comparison of annelid coenoses in wet soils with varying base saturation. Data of one sampling date for each site. Samples were taken between 1988 and 1977. N, L, S, E = study sites. Continued next page



Obviously, only some of the species occurring in wet soils indicate wet conditions (moisture values 8-10). These species have developed different strategies to cope with oxygen deficiency in soil. Species such as Eiseniella tetraedra and Cognettia glandulosa inhabit only the aerated region near the soil surface. Other species (e.g. Octolasion tyrtaeum tyrtaeum, Marionina filiformis) also occur in deeper soil strata, because they tolerate a lack of oxygen to a certain degree. Some endogeic earthworm species are capable of penetrating into anaerobic zones whilst maintaining 
Table 1. continued

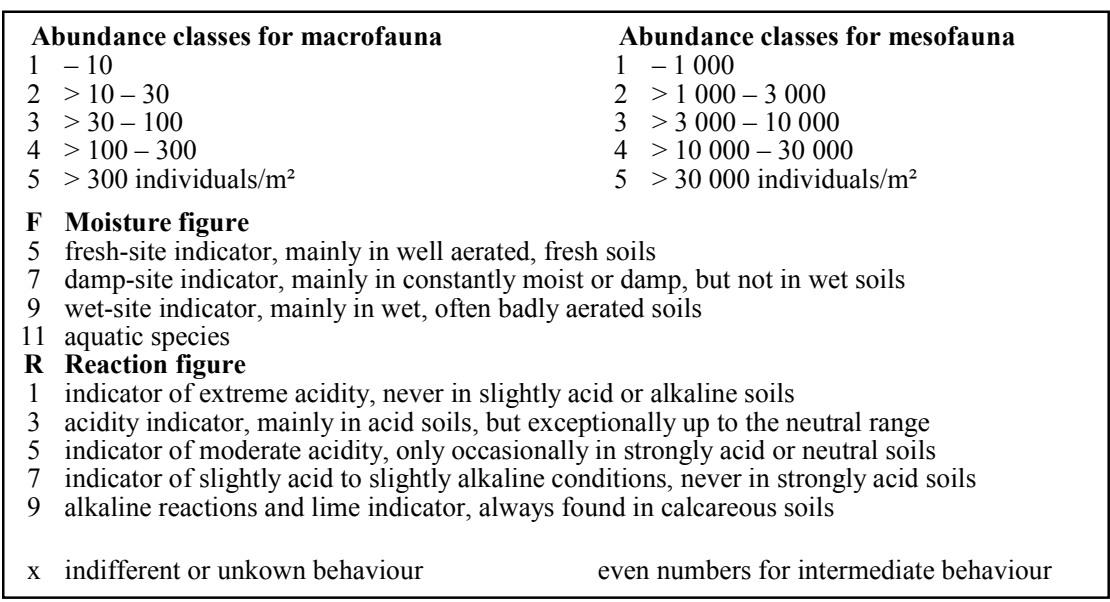

contact to aerobic conditions with their tail (Roots 1956; Bouché 1972). Deep burrowing (anecic) species do not inhabit soils with a permanently high groundwater table or waterlogged soils (Graefe and Beylich 1999; Keplin and Broll, this volume). Species that tolerate varying soil water contents might respond to temporary changes in soil moisture through vertical migration. The influence of hydromorphic conditions on the vertical distribution of enchytraeids is shown in Figure 1. The majority of worms are found in the uppermost layer rich in oxygen. Below 2.5 $\mathrm{cm}$, the two wet soils (BDF 33 and BDF 14) show low enchytraeid densities, while the vertical distribution is more even at the site BDF 25, which is better drained.

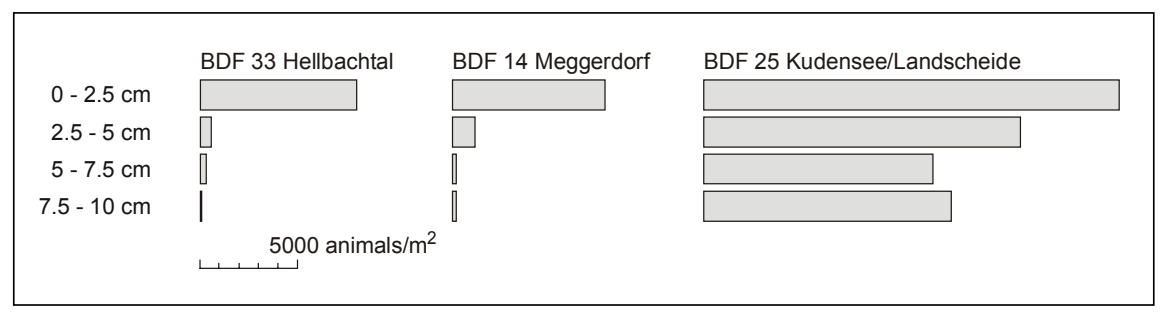

Figure 1. Vertical distribution of microannelids (earthworms excluded) on three sites used as grassland on fen (soil monitoring sites [BDF] in Schleswig-Holstein, Germany). BDF 25 with drainage, BDF 33 and BDF 14 without or with poor drainage 
Table 2. Site description for the sites referred to in Table 1

\begin{tabular}{|c|c|c|c|}
\hline \multicolumn{2}{|l|}{ Site } & Soil properties & Vegetation / Management \\
\hline \multicolumn{4}{|c|}{$\begin{array}{l}\text { Nature Park Schwalm-Nette } \\
\text { (Nordrhein-Westfalen) }\end{array}$} \\
\hline N1 & Piecksbruch & $\begin{array}{l}\text { fen, Histosol } \\
\text { very low base } \\
\text { saturation }\end{array}$ & Sphagnum bog with Myrica gale \\
\hline $\mathrm{N} 2$ & Elmpter Bruch & $\begin{array}{l}\text { Gleysol } \\
\text { very low base } \\
\text { saturation }\end{array}$ & Ericetum tetralicis \\
\hline N3 & Buscher Bruch & $\begin{array}{l}\text { fen, Histosol } \\
\text { low base saturation }\end{array}$ & $\begin{array}{l}\text { Carici elongatae-Alnetum sphagnetosum, } \\
\text { alder swamp with Carex acutiformis }\end{array}$ \\
\hline N4 & Rothbusch & $\begin{array}{l}\text { fen, Histosol } \\
\text { medium base saturation }\end{array}$ & $\begin{array}{l}\text { Carici elongatae-Alnetum iridetosum, } \\
\text { alder swamp with Carex acutiformis }\end{array}$ \\
\hline \multicolumn{4}{|c|}{$\begin{array}{l}\text { Sites in the surroundings of a } \\
\text { cement works near Lägerdorf } \\
\text { (Schleswig-Holstein) }\end{array}$} \\
\hline L1 & Winselmoor & bog, Histosol & fen birchwood on former peat cutting \\
\hline L2 & $\begin{array}{l}\text { Breitenburger } \\
\text { Moor }\end{array}$ & bog, Histosol & $\begin{array}{l}\text { fen birchwood on former peat cutting } \\
\text { pH elevated by deposition of alkaline dusts }\end{array}$ \\
\hline L3 & Winselmoor & bog, Histosol & $\begin{array}{l}\text { pasture fallow, previously drained and fertilized } \\
\text { peat bog, groundwater table recently raised } \\
\text { again }\end{array}$ \\
\hline \multicolumn{4}{|c|}{$\begin{array}{l}\text { Soil monitoring sites } \\
\text { (Schleswig-Holstein) }\end{array}$} \\
\hline S1 & $\begin{array}{l}\text { BDF } 14 \\
\text { Meggerdorf }\end{array}$ & fen, Histosol & pasture \\
\hline S2 & $\begin{array}{l}\text { BDF } 33 \\
\text { Hellbachtal }\end{array}$ & fen, Histosol & pasture, nature reserve \\
\hline \multicolumn{4}{|c|}{$\begin{array}{l}\text { Biosphere Reserve Elbtalaue near } \\
\text { Lenzen (Brandenburg) }\end{array}$} \\
\hline E1 & Eichwald & Gleysol & Caricetum gracilis \\
\hline E2 & Dreifelder & Gleysol & Phalaridetum arundinaceae \\
\hline E3 & Lütkenwisch & Gleysol & $\begin{array}{l}\text { Ranunculo-Alopecuretum geniculati } \\
\text { depression in an alluvial site, pasture }\end{array}$ \\
\hline
\end{tabular}




\section{Decomposer communities of wet soils}

The ecological behaviour of a species can be described by indicator values, strategy type and life form (Graefe and Schmelz 1999). Determination of the decomposer community (Table 3, as suggested by Graefe (1993a)) is a further step in characterising the biological soil state. The classification of decomposer community types follows the common practice in plant sociology. Community types are discriminated by character species. Since only annelids have been used as character species so far, the names of the community units have been derived from this taxon. However, this does not mean that other soil fauna groups might not be similarly useful in distinguishing decomposer communities. It should be noted that the development of plant communities, soil types, humus forms and decomposer communities takes place at different spatial and temporal scales. Therefore, the same decomposer community can occur in combination with different plant communities and soils (comp. Tables 1 and 2). For these reasons independent classification systems are required for these ecosystem subunits.

In wet soils we find primarily two types of decomposer communities which differ considerably regarding their species composition (type 1.3 and 2.2 in Tables 1 and 3). In acid soils such as peat bogs, the annelid coenosis consists mainly of wet-site indicators with low reaction values (reaction values 1-4) typical for the alliance Cognettion sphagnetorum. In contrast, soils with medium to high base saturation are inhabited mostly by wet-site indicators with the reaction value 7 (alliance Eiseniellion). In Table 1 the character species of these two decomposer communities are assembled in the framed areas. In both communities we find several species that lack a moisture value, as they do not show a particular preference for either wet or dry soils. Nevertheless, because most of them have a reaction value they can be considered character species on the order unit (framed with broken lines in Table 1). The differentiation between the decomposer communities of wet and aerated soils is made on the alliance level. A basic feature of decomposer communities in wet soils is the absence of anecic species. In neutral to moderately acid soils, their occurrence is a main criterion for distinguishing between Lumbricion and Eiseniellion (Fig. 2). In strongly acid soils, anecic species are generally absent, because they do not tolerate high soil acidity.

In nature transitional states of decomposer communities are found quite frequently. An example for this is included in Table 1. At site N4 neutrophil species occur as well as acid tolerant species. Similarly, a soil might be inhabited by freshsite indicators and wet-site indicators simultaneously. A transitional state generally suggests that the decomposer community is responding to changing environmental 
Table 3. Synopsis of decomposer community types with site examples

\begin{tabular}{|c|c|c|}
\hline Order & Alliance & Association \\
\hline \multirow{7}{*}{$\begin{array}{l}\text { 1. Lumbricetalia } \\
\text { Sites } \\
\text { moderately } \\
\text { acid to rich in } \\
\text { lime }\end{array}$} & \multirow[t]{2}{*}{$\begin{array}{l}\text { 1.1 Lumbricion } \\
\text { Undisturbed aerated soils }\end{array}$} & $\begin{array}{l}\text { 1.11 Stercuto-Lumbricetum } \\
\text { Forest with mull humus forms }\end{array}$ \\
\hline & & $\begin{array}{l}\text { 1.12 Fridericio-Lumbricetum } \\
\text { Grassland and arable land on } \\
\text { loamy soils }\end{array}$ \\
\hline & \multirow{3}{*}{$\begin{array}{l}\text { 1.2 Enchytraeion } \\
\text { Disturbed and eutrophicated } \\
\text { soils }\end{array}$} & $\begin{array}{c}\text { 1.21 Fridericio-Enchytraeetum } \\
\text { Arable land on sandy soils }\end{array}$ \\
\hline & & $\begin{array}{l}\text { 1.22 } \\
\text { Buchholzio-Enchytraeetum } \\
\text { Eutrophicated, compacted } \\
\text { soils under urban influence }\end{array}$ \\
\hline & & $\begin{array}{ll}1.23 & \text { Eisenietum } \\
\text { Compost sites }\end{array}$ \\
\hline & \multirow[t]{2}{*}{$\begin{array}{l}\text { 1.3 Eiseniellion } \\
\text { Water-saturated, badly } \\
\text { aerated soils }\end{array}$} & $\begin{array}{l}1.31 \text { Octolasietum tyrtaei } \\
\text { Fen, alder swamp, high base } \\
\text { saturation }\end{array}$ \\
\hline & & $\begin{array}{ll}\text { Eisenielletum } \\
\text { Semiaquatic sites, floodplain }\end{array}$ \\
\hline \multirow{2}{*}{$\begin{array}{l}\text { 2. Cognettietalia } \\
\text { Sites with acid } \\
\text { humus layer or } \\
\text { peat }\end{array}$} &  & \begin{tabular}{|l}
2.11 Achaeto-Cognettietum \\
Forest and heathland with \\
moder or mor humus forms
\end{tabular} \\
\hline & $\begin{array}{l}2.2 \text { Cognettion sphagnetorum } \\
\text { Wet organic soils with low } \\
\text { base saturation }\end{array}$ & $\begin{array}{l}2.21 \text { Cognettietum sphagnetorum } \\
\text { Fen, ombrotrophic bog, low } \\
\text { base saturation }\end{array}$ \\
\hline \multirow{2}{*}{$\begin{array}{l}\text { 3. Henleetalia } \\
\text { Sites } \\
\text { moderately } \\
\text { acid to rich in } \\
\text { lime with } \\
\text { humus layer }\end{array}$} & $\begin{array}{l}\text { 3.1 Mesenchytraeo-Henleion } \\
\text { Decomposition inhibited by } \\
\text { low temperature }\end{array}$ & $\begin{array}{l}3.11 \text { Mesenchytraeo-Henleetum } \\
\text { Permafrost soils in arctic } \\
\text { tundra }\end{array}$ \\
\hline & $\begin{array}{ll}\text { 3.2 } & \text { Fridericio-Henleion } \\
\text { Bioturbation inhibited by } \\
\text { lack of soil dwelling } \\
\text { earthworms }\end{array}$ & $\begin{array}{l}\text { 3.21 } \\
\text { Fridericio-Henleetum } \\
\text { Early succession stage in } \\
\text { reclaimed polders and } \\
\text { marshlands }\end{array}$ \\
\hline $\begin{array}{l}\text { nities } \\
\text { liffer }\end{array}$ & $\begin{array}{l}\text { uenced by salt } \\
\text { ted) }\end{array}$ & \\
\hline
\end{tabular}






Figure 2. Range of different decomposer communities in the life form diagram of earthworms (contribution of the three life forms in \% biomass). Points represent a variety of sites with different plant communities

conditions. This kind of transformation process often includes the disappearance of key stone species which are essential for the functioning and stability of the system. In the case of decomposer communities deep burrowing earthworms are considered key stone species because of their importance for bioturbation. Their disappearance (or reappearance) marks a distinct change in the performance of the decomposer community.

\section{Conclusions}

The system of decomposer communities provides a method for indicating natural or anthropogenically influenced soil forming processes. This approach has been 
used on several occasions in evaluating amelioration measures - liming, inoculation with earthworms (Graefe 1990, 1993a; Beylich 1995) - and for long-term monitoring (Graefe et al. 1998). Further fields of application are environmental impact assessment (Graefe 1993b) and prognosis of the ecological effects of landscape management (Graefe and Beylich 1999), where studies on soil biocoenoses are still greatly underrepresented.

Several studies have been carried out during the past years investigating the suitability of different soil fauna taxa in characterising wet habitats. Oribatid mites were found useful in distinguishing between different stages of degradation of mires in the area of Berlin by Kehl (1997). Collembola and mites were considered suitable bioindicators in floodplains by Wohlgemuth-von Reiche et al. (1997), while isopods, chilopods and diplopods were not. Spang (1996) examined lumbricids, snails and carabids in regard to their value in indicating the frequency of flooding in floodplains at the Upper Rhine. However, each of these studies concentrated on one kind of wet habitat only. Here, a system for characterising all kinds of wet habitats by representatives of the soil fauna has been presented. In this respect, terrestrial annelids show the advantage that they, unlike some other taxa, occur in almost every soil. So far the indicator values for terrestrial annelids and the system of decomposer communities have been established for Central Europe, but an extension to other geographical regions is conceivable. Also, for Central Europe adaptions will be made, if necessary, according to our increasing knowledge of the ecological behaviour of species.

\section{Acknowledgements}

The soil monitoring sites (BDF) were investigated on behalf of the LANU (State Agency of Nature and Environment of Schleswig-Holstein). The studies in the Biosphere Reserve Elbtalaue were supported by the BMBF (Federal Ministry of Education and Research) (FKZ 0339571).

\section{References}

Beylich A (1995) Ein Versuch zur Bodenverbesserung an sauren Waldstandorten: Auswirkungen auf die Zersetzergesellschaft. Newsletter on Enchytraeidae 4: 35-44

Bouché MB (1972) Lombriciens de France. Écologie et Systématique. Institut National de la Recherche Agronomique, Paris

Braun-Blanquet J (1964) Pflanzensoziologie. 3rd edition, Springer, Wien, New York

Dunger W (1983) Tiere im Boden. A. Ziemsen, Wittenberg Lutherstadt

Ellenberg H, Weber HE, Düll R, Wirth V, Werner W, Paulissen D (1992) Zeigerwerte von Pflanzen in Mitteleuropa. 2nd edition. Scripta Geobotanica 18

Graefe U (1990) Untersuchungen zum Einfluß von Kompensationskalkung und Bodenbearbeitung in einem bodensauren Buchenwald- und Fichtenforst-Ökosystem. In: Gehrmann J (ed) Umweltkon- 
trolle am Waldökosystem. Forschung und Beratung, Reihe C, Heft 48, Landwirtschaftsverlag Münster-Hiltrup, pp 232-241

Graefe U (1993a) Die Gliederung von Zersetzergesellschaften für die standortsökologische Ansprache. Mittlgen Dtschen Bodenkundl Ges 69: 95-98

Graefe U (1993b) Veränderungen der Zersetzergesellschaften im Immissionsbereich eines Zementwerkes. Mittlgen Dtschen Bodenkundl Ges 72: 531-534

Graefe U (1997) Von der Spezies zum Ökosystem: der Bewertungsschritt bei der bodenbiologischen Diagnose. Abh Ber Naturkundemus Görlitz 69, 2: 45-53

Graefe U, Elsner D-C, Necker U (1998) Monitoring auf Boden-Dauerbeobachtungsflächen: Bodenzoologische Parameter zur Kennzeichnung des biologischen Bodenzustands. Mittlgen Dtschen Bodenkundl Ges 87: 343-346

Graefe U, Beylich A (1999) Bodenbiozönosen als Ausdruck standörtlicher Bedingungen in der Elbtalaue. Auenreport, Sonderband 1: 88-95

Graefe U, Schmelz R (1999) Indicator values, strategy types and life forms of terrestrial Enchytraeidae and other microannelids. Newsletter on Enchytraeidae 7: 59-67

Healy B (1980) Distribution of terrestrial Enchytraeidae in Ireland. Pedobiologia 20: 159-175

Kehl C (1997) Die Hornmilbenzönosen (Acari, Oribatida) unterschiedlich stark degradierter Moorstandorte in Berlin und Brandenburg. PhD thesis, Free University of Berlin.

Keplin B, Broll G (2002) Earthworm coenoses in wet grassland of Northwest-Germany. Effects of restoration management on a Histosol and a Gleysol. In: Broll G, Merbach W, Pfeiffer, E-M (eds) Wetlands in Central Europe. Soil organisms, soil ecological processes and trace gas emissions. Springer, Berlin

Roots BI (1956) The water relations of earthworms II. Resistance to desiccation and immersion, and behaviour when submerged and when allowed a choice of environment. J Exp Biol 33: 29-44

Spang WD (1996) Die Eignung von Regenwürmern (Lumbricidae), Schnecken (Gastropoda) und Laufkäfern (Carabidae) als Indikatoren für auentypische Standortbedingungen. PhD thesis, University of Heidelberg

Walenciak O (1998) Osmoregulation, Volumen- und Ionenregulation von Lumbricus terrestris L. unter anaeroben Bedingungen und bei hyperosmotischem Streß. Diploma thesis, Free University of Berlin

Wohlgemuth-von Reiche D, Griegel A, Weigmann G (1997): Reaktion terrestrischer Arthropodengruppen auf Überflutungen der Aue im Nationalpark Unteres Odertal. In: Handke K, Hildebrandt J (eds) Einfluß von Vernässung und Überstauung auf Wirbellose. Arbeitsberichte Landschaftökologie Münster 18: 193-207

Zebe E, Heiden T (1983) Erdwürmer unter $\mathrm{O}_{2}$-Mangel: Untersuchungen über die Anaerobiose bei Eisenia fetida. Verh Dtsch Zool Ges 1983: 221 